\title{
Dr. J. M. Bell, FRGS: A Canadian Auxiliary Geographer in New Zealand
}

\author{
MICHAEL ROCHE
}

\begin{abstract}
Using Hodder's notion of "biography as method," this paper examines the geographical endeavours of James Mackintosh Bell, Director of the New Zealand Geological Survey from 1905 to 1911, in New Zealand and Canada. Canadian born, Harvard trained, Bell has a significant place in the history of geology in New Zealand and mining geology in Canada, yet much of his writing was explicitly geographical in orientation. This essay analyses this body of work and its significance and limitations in adding to and disseminating knowledge of the geography of NZ, particularly. Bell credentialed himself geographically as a Fellow of the Royal Geographical Society (FRGS). The FRGS were important builders of geographical knowledge in NZ from the 1850 s up to the establishment of university geography in the 1930s when formal geographical research commenced. Geologists were a numerically significant group amongst the NZ FRGS, distinctive in that they held university qualifications, and Bell was particularly wide ranging in his geographical interests.
\end{abstract}

\section{Introduction}

Geography was taught as a school subject in New Zealand at least from the 1870s, and sporadically in the university colleges, as an adjunct to commerce and geology, from the early 1900s, before the first standalone geography department was established at Canterbury College in 1937. Western geographical knowledge was, however, being accumulated locally from earlier times. From the 1850 s to the 1930 s, some such knowledge was gathered by individuals who consciously chose to label themselves "geographers" by virtue of being Fellows of the Royal Geographical Society of London (FRGS), adopting what Innis Keighren describes as "institutional warrants of credibility." The composition of this community, people who I am terming "auxiliary geographers," was diverse, with few members in New Zealand ever meeting together as geographers, so that they connected more to the metropole than to each other as FRGS. ${ }^{2}$ A fluid assembly, cumulatively numbering over 120 in NZ from the 1850s to the 1940s, they can be arranged into six groups based on a mix of occupation and interests: surveyors, geologists, teachers, mountaineers, travellers, and "gentlemen." From these groups, I have previously considered the geographical endeavours of surveyor-explorer J. T. Thomson, traveller-writer Frances Lysnar, and Geology Professor Noel Benson, who, as early as 1920, aspired to introduce the teaching of geography at the University of Otago. ${ }^{3}$ These inquiries may be thought of as instances of what historical geographer Jake Hodder termed "biography as method," that is, studying "the external factors that have shaped lives," as opposed to "biography as subject," although, in this present instance, it is not so much an abundance of primary material, but rather its scarcity and unevenness that informs the choice of approach. $^{4}$

Another of these geologists, James Mackintosh Bell (1877-1934), known as Mackintosh or "Mac Bell," is the focus of this paper. ${ }^{5}$ As a sizable subgroup of the FRGS in NZ, geologists were a

Journal of New Zealand Studies NS32 (2021), 108-122 https://doi.org/10.26686/jnzs.iNS32.6867 
distinctive cluster. They mostly had formal university training, unlike the majority of FRGS, generally attained beyond NZ, and in some cases to the doctoral level. They had professional positions either in the university system (other FRGS geologists included Professors Noel Benson and Patrick Marshall) or earlier as provincial government geologists (for example, Julius von Haast) and later in the New Zealand Geological Survey (NZGS, for example, Hartley Ferrar). Some were "imperial careerists"; the working lives of others were substantially played out in NZ. There was a convergence around surveying and map making, geological fieldwork, and topography, which produced from the 1860s to 1920s a shared and porous border between geology and geography, particularly in the Royal Geographical Society (RGS) tradition. Some of the geologists were also mountaineers above and beyond what was required for their professional needs. This renders the geologists an interesting subset of FRGS. Bell displays many of the group attributes, but these do not represent the fullness of his engagement with geography. He also undertook travel writing, notably in The Wilds of Maoriland, a report on his time in NZ, but also of his war time experiences (in the First World War), and later journeys in Russia and China. ${ }^{7}$

A nephew of Alexander Graham Bell, of telephone fame, and of Dr Robert Bell, Director of the Canadian Geological Survey (CGS, 1901-1906), James Mackintosh Bell took an MA at Queens College Ontario (now Queens University) and completed a PhD in geology at Harvard University in 1904. In 1899-1900, he undertook exploration work for the CGS. Late in 1904, from 57 applicants, he was offered and accepted a position in NZ as Geologist in the Mines Department, at a salary of $£ 600$ per annum. Bell remained in NZ until $1911 .^{8}$

\section{Canadian Preconditions}

Bell's first geographical paper was read in his absence at the July 1901 meeting of the RGS, along with another by Robert Bell on geological survey and mapping in Baffin Land. The implication is that Robert Bell, also a FRGS, had orchestrated the opportunity for his nephew, who would have presented his paper in person had not he had to return unexpectedly to Canada. Published in the September issue of Geographical Journal, the paper was an account of his "recent explorations" in the Mackenzie river region of Northern Canada, particularly of the Great Bear Lake, "thoroughly unexplored country rarely visited even by the natives."9 This journey was undertaken for the CGS, and Bell was acutely aware that he was travelling in the footsteps of only a few European explorers, including Sir John Franklin.

The paper took the form of a narrative of the journey interspliced with observations about topography and geology. The accompanying map was doubtless what Bell saw as his main contribution to geographical knowledge. Bell and his companions were not travelling across an empty landscape, and he recorded various engagements with local people. These were typically accompanied by judgmental comments. Thus, he labelled chief Itzekah of the Hareskin tribe [Sahtu Dene] as "a native of the most objectionable type."10 This was because Itzekah had questioned his reason for being there, demanded gifts, and warned Bell not to kill any caribou, least they disappear. Sahtu Dene he described as "little civilized," though Christianised, and in his CGS report $^{11}$ he called them "a handsome race, being tall and well built, and their picturesque deerskin coats and leggings ornamented with beads and porcupine quills given them a pleasing appearance." 12 Of a party of Inuit who ran off on his approach, he did concede "it is quite probable they may have expected an army behind us." ${ }^{13}$ Later on in the journey, Tlicho guides were recorded

Journal of New Zealand Studies NS32 (2021), 108-122 https://doi.org/10.26686/jnzs.iNS32.6867 
as "kindly, good-natured people, superior to their Hareskin [Sahtu Dene] neighbours to the north." 14

In 1901, Bell became a FRGS. The nomination document was signed by Dr J. S. Keltie, Assistant Secretary of the RGS and an editor of Geographical Journal, and E. A. Reeves. ${ }^{15}$ Keltie signed many of the nomination forms at this time, particularly when the candidate was based outside the UK. Reeves was a regular Geographical Journal contributor on surveying and field navigation. Bell's CGS link and his 1899 and 1901 publications would have been more than adequate qualification. FRGS was not equivalent to the fellowships awarded by other scientific societies, being rather a higher membership category, the subscription of which supported RGS activities. It was nevertheless a means of actively credentialing oneself as a geographer, particularly in the explorer-traveller mapping era, when the boundary between professional and amateur was blurred.

Bell reworked some material from the expedition in a paper, initially read before the Boston Branch of the American Folk-Lore Society, and subsequently published. ${ }^{16}$ Founded in 1888 , the American Folk Lore Society was comprised of museum staff, university staff, and lay members dedicated to recording and communicating folk traditions. Bell recounted various traditional stories of the Chippwyans [Denesuline] collected on his 1899-1900 expedition. He began with the statement that "throughout the Northern part of Canada still lie vast tracts of country where the white man has never been, and where the few remaining savages who there made their home are still as wild and uncivilized as when Columbus landed." ${ }^{17}$ In a note at the end of the paper he refers to great changes to Denesuline life caused by an influx of fur trappers since 1900, so there is a "recording a dying culture" element about his efforts. Bell discussed in detail three narratives: the big bird story, the white bear story, and the legend of Ithenhiela. He returned to Sahtu Dene and Chief Itzekah (though not by name) in more detail and more sympathetically than in his 1901 Geographical Journal paper. The Sahtu Dene and Tlicho "retained the purest customs and manners"; the Sahtu Dene were now "simple kindly and hospitable people anxious to do all they could to help us"; the Tlicho fed Bell and his party proper food, re-provisioned them, had their garments mended, re-clothed them, and guided them on their way. ${ }^{18}$

Bell's original account of his journey, published as a CGS bulletin report, was straightforward, containing both additional detail and presenting other events from a different point of view than in his later publications. For example, here he named his various travelling companions, guides and interpreters. ${ }^{19}$ Notable among them was Charles Camsell, hired by Bell at Fort Norman to assist with scientific work, who went on to have a distinguished career with the CGS and in the public service. ${ }^{20}$ Bell later named Mount Camsell in the Southern Alps of NZ after his former field assistant. In addition, Bell provided his first account of the Sahtu Dene and Tlicho people as "for the most part a harmless and good natured race." ${ }^{21}$ He also expanded on why the Inuit had run from Camsell and him; "they had evidently learned from their forefathers of the murderous treatment which their people had received from Herne and his followers while exploring the Coppermine [River]." 22 This was a reference to Samuel Herne, a Hudson Bay Company employee, who had explored the Coppermine River looking for copper deposits in 1771, when over 20 Inuit were killed in the "Bloody Falls massacre." Much later, in Far Places, he included additional details about the massacre. ${ }^{23}$ Bell also referred to the difficulty his party faced on parts of the

Journal of New Zealand Studies NS32 (2021), 108-122 https://doi.org/10.26686/jnzs.iNS32.6867 
journey where they were without guides. In 1909, some of the stories from his 1903 folklore paper were included in a jointly authored compilation of stories retold "for White Children."24

Bell's interest in the native peoples he encountered on his Great Bear Lake travels was, however, more than personal or discretionary. The CGS was charged with gathering natural history specimens. This charge was later extended to building up ethnological collections, often framed in Darwinian evolutionary terms of stronger European races replacing weaker aboriginal ones. Dr. Robert Bell had hired Franz Boas to advance this work in the late 1880s, only to find he would put forward a contrary view based on "traditions or myth" rather than "hereditary descent." 25 J. M. Bell's interest in native peoples seems anchored by the Darwinian anthropological precepts of the CGS.

\section{A New Zealand Sojourn, 1904-1911}

In 1904, at the age of 27, Bell was appointed as geologist to the Mines Department in NZ. He arrived in February 1905, and within a year had parlayed this up to becoming Director of the Geological Survey, a position previously held by Sir James Hector, but unfilled since $1893 .{ }^{26} \mathrm{He}$ moved with speed to separate the Survey from the Mines Department and initiated a new round of geological investigations. Back copies of CGS and national geological survey reports were obtained. The staff were reorganised and expanded. Systematic areal mapping was undertaken at 1:63,360 scale, and focused on economic geology. Over a dozen NZGS bulletins were published before his departure. ${ }^{27}$ Bell was notably mobile during his time in NZ, as his annual reports testify, with field seasons sometimes stretching from September to April (spring to autumn).

Although 4,000 square miles [1.03 mill ha] had been mapped in five years, at that rate of progress it would still have taken until the twenty-first century to map the entire country. ${ }^{28}$ There was later criticism that his inch-to-the-mile mapping did not match the detail of earlier inch-to-four-miles mapping work and that Bell was overly concerned with economic geology. ${ }^{29}$ The centennial history of the NZGS, somewhat disapprovingly for a celebratory volume, characterised Bell as "an organizer, but once the job was progressing it lost its challenge. . . [He was] too impatient for results ... too restless to be concerned with the deeper aspects of geological problems which needed study at that point in the country's development."30

Bell was the sole or joint author of four of the eleven new series NZGS bulletins published while he was in NZ. Another appeared after his departure. That the CGS model shaped his approach and interests is evident from the structure of the NZGS bulletins. Although they all have a solid middle section on the geology of the area under study, they are prefaced by a general historical and cultural chapter as well as a physical geography and topography chapter, and conclude with a chapter on economic geology. The latter was doubtless a shrewd move to maintain resources and political support for the NZGS, though it directed attention to remoter areas of the country and away from systematic coverage. But in the longer run, it also pointed to an element of Bell's character and deeper professional interests: it was to the higher risk-and-rewards fields of mining and engineering geology that he would ultimately gravitate. Physical geography and topographical survey, an important aspect of his Great Bear Lake, were part of the new NZGS bulletins. Topographical as well as geological mapping was completed, and typically Bell also wrote an

Journal of New Zealand Studies NS32 (2021), 108-122 https://doi.org/10.26686/jnzs.iNS32.6867 
evaluation of the scenery of the district: for example, "there is no finer gem in New Zealand scenery than Lake Kanieri." 31 Bell's influence in this respect is shown by the absence of cultural and historical details and physical geography from NZGS bulletins completed after his departure from NZ. ${ }^{32}$

\section{Bell as Geographer in New Zealand}

The NZGS bulletins were not the sole outlet for his writing. The glaciers and volcanoes of NZ quickly attracted Bell's attention. Of the Southern Alps, he wrote, after visiting glaciers in February 1906, "I was greatly impressed by the ice features, and their really wonderful proportions, considering the relatively low altitude of the country and the relative proximity of the equator." 33 He enjoyed travel and spending time in the field. Six months after his arrival, he published a paper on the physiography of the South Island for an American audience in the Bulletin of the American Geographical Society (now Geographical Review). ${ }^{34}$ Likewise, enthralled by the 1886 Tarawera volcanic eruption, he visited the area and wrote, incorporating local secondary sources, a paper on the district, including photographs (likely his own), which was published in Geographical Journal in 1906, twenty years after the event. ${ }^{35}$

In 1907, he visited Mount Ngauruhoe and Mount Ruapehu, returning in the following years until, in 1910, he successfully made an ascent of both the volcanoes. This was later reported on in Geographical Journal, along with remarks about all the major volcanoes of NZ. ${ }^{36}$ By this time, he had resigned from the NZGS. ${ }^{37}$

Bell, in 1907, secured five months on half pay to return to Canada to complete some private business, on the understanding that he would continue with editorial work on the NZGS bulletins. To assist his case, he stated his intention to purchase essential laboratory equipment. But this was not the sum of the trip, for Bell gave lectures at Yale, Harvard, Princeton, and Queens University as well as in London to the RGS and the Royal Colonial Institute. ${ }^{38}$ Some of these lectures were professional, but others were geographical in orientation, such as his October 1907 presentation at Harvard was on "Travel in Little Explored Parts of New Zealand." ${ }^{39}$ He delivered two lectures to the RGS in August 1907 and again in 1908. The 1907 lecture was labelled "The Heart of the Southern Alps, New Zealand," and lyrically said of the range that it presents "many features of remarkable interest to the glaciologist and physiographer and exhibits an area of country of rare charm to the observant alpinist and explorer." 40 He followed this with a further paper in 1908, "The Douglas Glacier and its Neighbourhood." This reported on a summer 1906-07 journey by Bell and others "to gain general geological and geographical knowledge of a wild and interesting section" of the Southern Alps. ${ }^{41}$ The journey had the subsidiary goal of finding a pass from Westland to the Mueller Glacier and thence easy access to the Hermitage at Aoraki/Mount Cook. The first half of the paper described the trip, which was considerably hampered by poor weather. The second provided a detailed account of the Douglas Valley, the Karangarua Valley, the McKerrow-Landsborough Valley, the Copeland Valley, and related glaciers. Again, Bell was moved beyond scientific description. Of the Douglas Valley, he wrote, "the picture is aweinspiring rather than beautiful, but there is a certain wild and savage charm about it which brings its main features constantly back to one's memory long after the details of the wonderful ensemble have faded." 42 The presentation, illustrated by slides and with an accompanying map and

Journal of New Zealand Studies NS32 (2021), 108-122 https://doi.org/10.26686/jnzs.iNS32.6867 
illustration, was subsequently published in Geographical Journal. ${ }^{43}$ His RGS and Royal Colonial Institute lectures were reported on in detail in NZ newspapers. ${ }^{44}$

In 1910, Bell also produced A Geographical Report on the Franz Josef Glacier. This was based on summer fieldwork in 1908 and 1909. As well as a detailed description of the glacier and two new maps, it contained short sections on climbing routes and the scenery of the glacier: "one is struck with amazement at the marvellous beauty and extraordinary characteristics of this wonderful ice-river flowing in its lower part through a forest almost subtropical in its luxuriance." 45

Bell gave several illustrated lectures to NZ audiences. Initially, these were on Canadian topics, such as a lecture on "Eighteen Months in the Canadian Far North" to the Otago Institute. Later, there were repeat versions of his RGS talk on the Southern Alps in Palmerston North, as well as "The Volcanoes of New Zealand" at the Lays Institute Library in Auckland. ${ }^{46}$ In 1910, the NZ government declined permission for Bell to accompany Captain Scott's Terra Nova expedition to the Antarctic. It is unclear if this had any bearing on his decision in December that same year to resign his position, but he was very disappointed at the time. ${ }^{47}$

In "The Douglas Glacier and its Neighbourhood," in addition to a narrative of difficult travel, Bell provided maps, photographs, and description of glaciers. ${ }^{48}$ The U-shaped valleys were identified as glacial in origin, but he made no real attempt to situate the account within a wider literature. The ensuing discussion of the paper at the RGS raised such points. Dr Aubrey Strahan, prefaced his remarks with the comment that, "Though it occupies a somewhat subordinate position on the wall-map hung in this room, it [NZ] certainly includes some of the most noteworthy phenomena to be found." 49 The former greater extent of glaciers and the proximity of some to sea level was significant, as was the synchrony (or lack of it) of the ebb and flow of glaciers in both hemispheres. Douglas Freshfield, the RGS expert in the field, pointed to the imminent measurement of Himalayan glaciers, welcoming new information from the USA, Canada, and NZ and, while uncertain about the cause of "glacial oscillations," expressed the view that with more data, "I have no doubt in time we shall have a scientific theory for all the movements of glaciers." ${ }^{50} \mathrm{NZ}$ was a source of interesting data, but the piecing together of the general theory would be done at the metropole.

In 1914, Bell published a book of 250 pages entitled The Wilds of Maoriland, recounting his time in NZ, particularly in some of its more remote corners. Its appearance in July, two months before WWI broke out, probably hampered its sales. In the introduction, he suggested his purpose was to encourage visitors to NZ. He was almost apologetic about the final chapter: "I conclude my traveller's tale with a description of the geography and climate of New Zealand - very dull reading, I fancy, for the average reader, but serving, perhaps, to illuminate to some extent, for the geographer the areas described in the previous chapters." 51

The individual chapter contents can be connected to Bell's previous geographical and geological writing (Table 1).

Journal of New Zealand Studies NS32 (2021), 108-122 https://doi.org/10.26686/jnzs.iNS32.6867 
Table 1: Aligning The Wilds of Maoriland with Bell's Other Writing

\begin{tabular}{|c|c|c|c|}
\hline & $\begin{array}{l}\text { The Wilds of } \\
\text { Maoriland }\end{array}$ & Articles & $\begin{array}{l}\text { NZGS Bulletin and other } \\
\text { publications }\end{array}$ \\
\hline Chapter 1 & $\begin{array}{l}\text { From Whangaroa } \\
\text { to the North Cape }\end{array}$ & $\begin{array}{l}\text { J. M. Bell and E. Clarke, "A Geological } \\
\text { Reconnaissance of Northernmost New } \\
\text { Zealand," Transactions and Proceedings } \\
\text { of the New Zealand Institute } 42 \text { (1909): } \\
613-24 .\end{array}$ & $\begin{array}{l}\text { J. M. Bell and E. Clarke, The } \\
\text { Geology of the Whangaroa } \\
\text { Subdivision, Hokianga Division } \\
\text { (1909). }\end{array}$ \\
\hline Chapter 2 & $\begin{array}{l}\text { Rambles on the } \\
\text { Hauraki Goldfields }\end{array}$ & $\begin{array}{l}\text { J. M. Bell, "The Mineral Wealth of New } \\
\text { Zealand," Proceedings of the Royal } \\
\text { Colonial Institute } 39 \text { (1907-08): 37-55. }\end{array}$ & $\begin{array}{l}\text { AJHR C9, 1908, 11-13: Tairua } \\
\text { goldfield plus map. } \\
\text { J. M. Bell The Hauraki } \\
\text { Goldfields, Australian Institute of } \\
\text { Mining Engineers (1912). }\end{array}$ \\
\hline Chapter 3 & Mayor Island & $\begin{array}{l}\text { J. M. Bell, "Some New Zealand } \\
\text { Volcanoes," Geographical Journal } 40 \\
\text { (1912): 8-23. }\end{array}$ & \\
\hline Chapter 4 & $\begin{array}{l}\text { Among the } \\
\text { Volcanoes }\end{array}$ & $\begin{array}{l}\text { J. M. Bell, "The Great Tarawera } \\
\text { Volcanic Rift," Geographical Journal } \\
27 \text { (1906): 369-82. } \\
\text { J. M. Bell, "Some New Zealand } \\
\text { Volcanoes," Geographical Journal } 40 \\
\text { (1912): 8-23. }\end{array}$ & \\
\hline Chapter 5 & $\begin{array}{l}\text { Through the } \\
\text { Urewera Country }\end{array}$ & & $\begin{array}{l}\text { AJHR C9, 1908, 9-10: Urewera } \\
\text { country. }\end{array}$ \\
\hline Chapter 6 & $\begin{array}{l}\text { The Wilds of } \\
\text { Karamea }\end{array}$ & & $\begin{array}{l}\text { AJHR C2 1906: geological survey } \\
\text { of North Westland commences. } \\
\text { AJHR C9, 1908: map of Karamea } \\
\text { division, facing page } 8 \text {. }\end{array}$ \\
\hline Chapter 7 & $\begin{array}{l}\text { The Heart of the } \\
\text { Southern Alps }\end{array}$ & $\begin{array}{l}\text { J. M. Bell, "A Physiographic Section } \\
\text { through the Middle Island of New } \\
\text { Zealand," Bulletin of the American } \\
\text { Geographical Society } 38 \text { (1906): 273- } \\
81 . \\
\text { J. M. Bell, "The Heart of the Southern } \\
\text { Alps, New Zealand," Geographical } \\
\text { Journal } 30 \text { (1907): 181-97. }\end{array}$ & $\begin{array}{l}\text { AJHR } 1909 \text { C9, 10-11: Franz } \\
\text { Josef glacier. } \\
\text { J. M. Bell, A Geographical Report } \\
\text { on the Franz Josef Glacier with } \\
\text { Topographical Maps and data by } \\
\text { Reginald Greville and Botanical } \\
\text { Notes by Leonard Cockayne } \\
\text { (1910). }\end{array}$ \\
\hline Chapter 8 & $\begin{array}{l}\text { The Great Douglas } \\
\text { Glacier }\end{array}$ & $\begin{array}{l}\text { J. M. Bell, "The Douglas Glacier and its } \\
\text { Neighbourhood," Geographical Journal } \\
\text { (1908): 32, 121-34. }\end{array}$ & \\
\hline Chapter 9 & $\begin{array}{l}\text { The Geography and } \\
\text { Climate of New } \\
\text { Zealand }\end{array}$ & $\begin{array}{l}\text { J. M. Bell, "The Physical Features of } \\
\text { New Zealand," Bulletin of the } \\
\text { Geographical Society } \\
\text { of Philadelphia } 8 \text { (1910): } 1-16 .\end{array}$ & \\
\hline
\end{tabular}

Journal of New Zealand Studies NS32 (2021), 108-122 https://doi.org/10.26686/jnzs.iNS32.6867 
Aligning Bell's other publications with the chapters of The Wilds of Maoriland makes is easier to see how he was able to draw on his fieldwork and official publications, using these as a basis for a more general travelogue and geography, and to prepare his book manuscript relatively quickly. In the case of the glaciers of the South Island, Bell wrote of his travel to and exploration of them, about their mapping, and about the physiography of the region. What is notable here is that he was able to write in different modes, each reinforcing the other rather than just repeating paragraphs verbatim.

In retrospect, Bell's chapter "Through the Urewera Country" is of interest because here, in 1916, only two years after the publication of Bell's book, Rua Kēnana, the Ringatū prophet, would be arrested by the police in what has been labelled the "worst clash between the police and a Maori community" in the twentieth century. ${ }^{52}$ Bell describes a two and a half weeks journey in February and March of 1908, with Jack Clark, into remote and inaccessible country. Bell indicated the discovery of gold at nearby Whakatane had prompted an official desire to know if quartz gold existed in the Urewera, which provided him with an opportunity to venture to "an area he had long wished to explore." 53 Bell quickly ascertained that "quartz is exceedingly rare," and there was no prospect of miners coming into the district. ${ }^{54}$ Just as in his Great Bear Lake exploration of 1899, he was interested in Māori lore. ${ }^{55}$ Here Hugh McPherson, "our clever Maori guide and interpreter," was of considerable assistance. ${ }^{56}$ Bell's interest was, however, framed within a view of Māori, along with other indigenous peoples, as displaying physical and cultural disintegration. A footnote that canvassed land transactions and war from the 1840s to 1860 s was exceedingly pro-settler in nature. The route that Bell proposed to take was via tracks and rough stock routes by way of Rua Kēnana's settlement at Maungapōhatu. Kēnana was presented dramatically: "Rua so we learned, hated the white people, and had gathered far and wide such of his people as would accept his cult at his great new pa of Maunga Pohatu ... where he attended to their spiritual and temporal needs." 57 Approaching Maungapōhatu, Bell referred to the "surpassing beauty" of Rua's headquarters: "it was evident that the well-made clearings surrounding the $p a$ are very recent." 58 He also described "the imposing habitations of the prophet, which rose, fresh and clean above the new clearing." 59 He was told Rua intended "to carve a new Jerusalem out of a primeval forest."60 Bell particularly applauded the complete clearing of the bush including stumps as progressive land development, and described the village in some detail. The circular meeting hall and temple, Hiona (Zion), was described in some detail: "a round building of about 75 feet $[23 \mathrm{~m}]$ in diameter and 30 feet $[9 \mathrm{~m}]$ in height, surrounded by a cupola, from which an elevated gangway led to a small rostrum situated immediately above the stockade... its walls were gaily decorated over a background of yellow, by mystic signs in pale blue and white." 61 Rua's followers welcomed Bell and his party; Rua himself, however, did not appear, but "he kept concealed," and Bell confessed "we felt disinclined to trust ourselves within the enclosure." 62

Perusal of The Wilds of Maoriland reinforces Burton's (1965) judgement: Bell acknowledges his enjoyment of fieldwork, particularly of travelling to the more distant corners of NZ. In a sense, The Wilds of Maoriland is "Explorations in the Great Bear Lake Region" writ large. It is a travel book, but not the standard travel book in that the text was a fusion of three narratives. One was a conventional account of the journeys of Bell and his companions, those he meets, the scenery and the joys and difficulties of venturing around the country. The second, intermingled with the first, was a quite detailed description of the physiography of the land (including comments on vegetation

Journal of New Zealand Studies NS32 (2021), 108-122 https://doi.org/10.26686/jnzs.iNS32.6867 
and climate), more so than any lay author would have attempted. Third was an ethnographic strand: Bell fills some space recounting the Māori he meets and repeating their stories relating to specific places and events, albeit that the accounts are buttressed by local ethnologist Percy Smith's work and not reliant just on his informants. He carried something of a "dying race" mentality across from his Canadian explorations, and said comparatively rather little about settler society and economy. Yet for someone who obviously enjoyed the challenge of fieldwork, he was also part of Wellington society. In June 1909, he was engaged to, and on 23 September 1909 he married, Vera Beauchamp, daughter of Sir Harold Beauchamp, a prominent businessman and chairman of the Bank of New Zealand and father of short-story writer Katherine Mansfield. ${ }^{63}$

The last chapter, "Geography and Climate of New Zealand," at 25 pages shorter than many of the others in the book, demonstrates what Bell considered to be "geography": it consisted of a quite detailed discussion of the physiography of the country, with a considerable reference to the underlying geology. The past and present vegetation, and the major land uses were described. Māori received occasional mention. There was a rare (and inaccurate) predictive comment, that the development of the abundant "water power" would "make New Zealand a manufacturing country." 64 He covers the whole country, so his account is regional but only in a rudimentary manner. Likewise, while physiography provides the platform on which society and economy takes form, the relationship between environment and society is not explicitly spelt out, through Bell seems at the softer end of environmental determinism spectrum: "influences" rather than "determines." Exceptionally, much of this final chapter is comprised of paragraphs taken directly from his paper on the physical features of NZ, interlaced with new text about society and economy. ${ }^{65}$ Perhaps he was hurrying to finish the manuscript?

\section{Bell as a Canadian Auxiliary Geographer}

After Bell resigned from the NZGS in 1911, he journeyed to London via New Caledonia, where he inspected mineral deposits at Koumac. In London, in partnership with a former NZGS colleague, Colin Fraser, he worked as a mining engineer. For a significant part of 1912-1913, Bell was on the Kirghiz steppe in Siberia, investigating coal mines and searching for suitable materials for fluxing copper ore, of which there had been discoveries, as well as studying water supply problems. ${ }^{66}$ Here, he added Russian to his fluency in French. Perhaps some of The Wilds of Maoriland was completed at this time? Bell returned to Canada, becoming a consulting geologist for Hamilton, Erlich, and Turk (1913-1927), after which he worked on his own account as a geologist, and served as a managing director of various Canadian mining companies. ${ }^{67}$ During the First World War, Bell joined the Canadian forces, rising to the rank of Major, and he later wrote about his wartime experiences in Siberia during 1917-1919. ${ }^{68}$ After the war, he continued to speak, giving a series of nine lectures in January 1920 on economic geology at Harvard. These commenced with the Waihi goldfield in NZ, and included as well as other copper, nickel, and goldmining areas in Australia, Siberia, and Canada. ${ }^{69}$

In the 1920s, Bell was successfully involved in development by the Huronian Company of the Keeley silver mine, and was a managing director of its Pioneer Mine. Bell had secured the liquidator's option when the original Keeley mine failed. Dividends of 20 percent were paid to shareholders in the mid-1920s. ${ }^{70}$ In 1928, he became managing director of the Atlas Exploration Company. ${ }^{71}$ The impression is of Bell as now comparatively well off, able to write about his travels

Journal of New Zealand Studies NS32 (2021), 108-122 https://doi.org/10.26686/jnzs.iNS32.6867 
as a mix of topography, geology, and scenery, but increasingly about the journey itself. From the perspective of today, Bell's writing reveals as much about the mores of early twentieth-century settler societies as it does about the subjects of his accounts.

Geography was increasingly prominent in Bell's writing in the 1920s. He published a paper on Great Slave Lake in Geographical Review in 1929, and delivered an "illustrated lecture" to the American Geographical Society on "The Great Lakes of the Far Canadian North West" in 1932. ${ }^{72}$ He had returned to the lakes in 1920 and 1921, undertaking mineral exploration, but took pleasure in an easy return trip by boat and train in 1928 to look over lands he had walked across in 1899. He further wrote of this in two chapters of Far Places, which is otherwise about his wider travels over previous decades. ${ }^{73}$ In Far Places, he wrote increasingly about the people with whom he had travelled, and others he had encountered. While Bell now included episodes in which he makes fun of himself - for example, over losing the one reliable compass in a lake - his accounts of his "halfcaste" guides are at best patronizing, though probably not exceptional at the time.

His most definitive declaration about geography also came in Far Places.

In writing Far Places I confess to a definite object. Behind the descriptions of remote localities, the details of adventures, lurks the hope that the book may, in some small measure, encourage an interest in the science of geography. The word stirs memories of childhood days, of laborious learning of the names of countries, their capital cities and other important towns, their physical features, the principal commodities each produces. But geography is much more than that. Without a knowledge of it, how can we understand history, and the tangled sequence of political events? How can we visualise the economic development of the world from those dark ages of the past when man was a wild animal hunting his prey much as the wolf does today, to this period of aeroplanes, of telegraphs and radios. ${ }^{74}$

He rejects nineteenth-century "capes and bays" geography in favour of a more expansive approach: "Geography describes the earth's surface as it is to-day and accounts for the distribution of its activities and life. it is the background of human society and of the diverse endeavours of mankind." 75 In some ways, this is remarkably consistent with what he attempted in the last chapter on "Geography and Climate" in The Wilds of Maoriland, though by 1931 his views were reinforced by having seen first-hand Arctic, steppe, temperate, and tropical environments. He still did not, however, expand on what he meant by "accounts for," which allows for a range of deterministic positions. On the other hand, in Bell's view, neither was geography to be limited to the academy in terms of the production and consumption of geographical knowledge: he did not want to perpetuate geography as "dull reading." was a Vice President of the Royal Canadian Geographical Society. Bell presumably saw the society and its journal as a Canadian variant of the RGS Geographical Journal, but it is worth noting that there may be other oblique family influences: Gilbert H. Grosvenor, the son-in-law of Alexander Graham Bell was the editor of National Geographic. The Royal Canadian Geographical Society had been founded in 1929 by his former field assistant Charles Camsell, who served as its President from 1930 to $1941 .^{77}$ Even so, beyond his travel writing, Bell was peripherally engaged with academic geography. Around 1928, along with another Canadian geologist, he had been considered by Harold Innis as a candidate for the foundation geography position at the University

Journal of New Zealand Studies NS32 (2021), 108-122 https://doi.org/10.26686/jnzs.iNS32.6867 
of Toronto. The eventual appointee was Australian Griffith Taylor, then at the University of Chicago. $^{78}$

\section{Conclusion}

Bell, through his illustrated lectures and more so through his writing, acted as a geographer. Apart from his NZGS bulletins, most of Bell's writing for journals and his books were not a requirement of his job. There was no remuneration; his income after 1911 came from his geological consultancy work (excluding royalties for his books, and they would surely not have been excessive). He consistently made use of his FRGS to credential all but his geological writing. The journey was as important for Bell as the destination. Bell in travel writer mode presents NZ as a distant land, but one that European travellers ought to include on their itinerary. Bell as scientist and geographer engages with NZ in a different way. This is especially evident in his discussion of glaciers. University training in geology meant that Bell drew on a specialised understanding of physiography to provide more accessible, though often still quite challenging, interpretations of landscape evolution, which sets him apart from the mainstream of the geography-as-travel-writing genre.

But what sort of geography was Bell performing? It was, and clearly remained, in the RGS (and American Geographical Society) tradition of exploration, mapping, and travel writing, and Bell was well travelled in some distant places, for his UK and North American audiences. He was also one of a handful of NZ-based FRGS to actually deliver lectures at the RGS.

Bell did write a more formal geography of NZ as the final chapter of the Wilds of Maoriland. This account was strong on the geomorphology of the country, described in dynamic terms and not as an unchanging landscape, but he only introduced a human element as an extension of discussion of physical features. He did refer to numerous Māori settlements around Lake Taupo but looked backwards to refer to "battles which raged here in the fighting days of olden times."79 It was not that Bell was disinterested in indigenous peoples - consider his first publication - but he seems to have considered them as relics of the past. This is consistent with Avrith-Wakeam's characterisation of CGS "beliefs about the inevitability of Indian extinction and the urgent need for immediate ethnological salvage." 80

Bell's books and other publications also built up a certain sort of geographical knowledge about NZ, for consumption, especially by Geographical Journal readers. This was a body of work that was comparatively orderly and "accurate," that could be drawn on as the discipline became established in the NZ university system. There is a latent environmentalist streak to Bell's work, but like Patrick Marshall, FRGS, Professor of Geology at Otago University, and author of the textbook The Geography of New Zealand, he thought of environmental "influences" rather than environmental "controls." This would have made his writing acceptable to the initial NZ university geography appointee, George Jobberns. ${ }^{81}$

Bell has moved from one imperial periphery to another, from Canada to NZ and back to Canada. He was ultimately more interested in expanding the frontiers, that is the breath, rather than the depth of knowledge. NZ was a source of new data, not of theory. But his travelogues did connect with lay readers, and he could provide a mix of vivid description of distant landscapes with a

Journal of New Zealand Studies NS32 (2021), 108-122 https://doi.org/10.26686/jnzs.iNS32.6867 
commentary on the nature of the landforms. Enjoying the act of travel, he was the interpreter and translator of information, including that provided by first nations people in Canada and Māori in $\mathrm{NZ}$, as well as specialist physiographical understanding, to a wider lay readership.

\footnotetext{
${ }^{1}$ Innis Keighran, "Geographies of the Book: Review and Prospect," Geography Compass 7 (2013): 749.

${ }^{2}$ For instance, Bell thanked Percy Smith in the Preface to The Wilds of Maoriland (London: Macmillan, 1914), acknowledging him not as a kindred FRGS but as a former Surveyor-General and source of information about Māori. Others met through their common membership of other organisations such as branches of the New Zealand Institute or the Polynesian Society.

${ }^{3}$ Michael Roche, "Frances B. Lysnar: New Zealand's First Woman FRGS, 1913," Geographical Journal 182 (2016): 429-37; Michael Roche, "John Turnbull Thomson, Fellow of the Royal Geographical Society: An Early New Zealand Geographer," New Zealand Geographer 72 (2016): 3-13; Michael Roche, "Noel Benson and Geology's Ambition for Geography at Otago University in the 1920s and 1930s" (paper presented to the New Zealand Geography Conference, University of Otago, Dunedin, 1-4 February 2016).

${ }^{4}$ Jake Hodder, "On Absence and Abundance: Biography as Method in Archival Research," Area 49 (2017): 455.

${ }^{5}$ Anon., "James Mackintosh Bell [obituary]," Canadian Geographical Journal April (1934): 197-98; Alan Mason, "Bell James Abbott Mackintosh," Dictionary of New Zealand Biography, Te Ara-The Encyclopedia of New Zealand, 1996, https://teara.govt.nz/en/biographies/3b25/bell-james-abbottmackintosh.

${ }^{6}$ David Lambert and Alan Lester, Colonial Lives across the British Empire: Imperial Careering in the Long Nineteenth Century (Cambridge: Cambridge University Press, 2006).

${ }^{7}$ Bell, The Wilds of Maoriland; James Mackintosh Bell, Side Lights on the Siberian Campaign (Toronto: Ryerson Press, 1922); James Mackintosh Bell, Far Places (Toronto: Macmillan, 1931).

${ }^{8}$ The government had initially approached New Zealand geologist James McLaren, then in the Indian Civil Service, but the salary was unattractive to him. See "A Government Geologist Appointed," Otago Daily Times, 25 November 1904, 7.

${ }^{9}$ James Mackintosh Bell, "Explorations in the Great Bear Lake Region," Geographical Journal 18 (1901): 249.

${ }^{10}$ Bell, "Explorations in the Great Bear Lake Region," 252.

${ }^{11}$ James Mackintosh Bell, Report of the Topography and Geology of the Great Bear Lake and of a Chain of Lakes and Streams thence to Great Slave Lake (Ottawa: Geological Survey of Canada, 1899), 10C.

${ }^{12}$ Bell, "Explorations in the Great Bear Lake Region," 252.

${ }^{13}$ Bell, "Explorations in the Great Bear Lake Region," 255.

${ }^{14}$ Bell, "Explorations in the Great Bear Lake Region," 258.

${ }^{15}$ James Mackintosh Bell, FRGS nomination form, 1901 (London: Royal Geographical Society Library).

${ }^{16}$ James Mackintosh Bell, "The Fireside Stories of the Chippwyans," The Journal of American Folk-Lore 16 (1903): 73-84.

${ }^{17}$ Bell, "Fireside Stories," 73.

${ }^{18}$ Bell, "Fireside Stories," 74.

${ }^{19}$ Bell, Report of the Topography of the Great Bear Lake, 1C-15C.

20 "Charles Camsell, Arctic Explorer, Son of the North," https://www.charlescamsell.com/.

${ }^{21}$ Bell, Report of the Topography of the Great Bear Lake, 10C.

${ }^{22}$ Bell, Report of the Topography of the Great Bear, 15C.

${ }^{23}$ Bell, Far Places.
}

Journal of New Zealand Studies NS32 (2021), 108-122 https://doi.org/10.26686/jnzs.iNS32.6867 
${ }^{24}$ Abby Brown and James Mackintosh Bell, "Foreword," in Tales of the Red Children (New York: Appleton-Century, 1935) [first edition 1909]. Brown, from Massachusetts, wrote numerous children's books and was a member of the American Folk-Lore Society, which probably provides the link to Bell's material. Tales of the Red Children went through many reprints. My copy dates from 1935, by which time both the authors were deceased, Brown in 1927 and Bell in 1934.

${ }^{25}$ Gail Avrith-Wakeam, "George Dawson, Franz Boas and the Origins of Professional Anthropology in Canada," Scientia Canadensis 17 (1993): 198.

${ }^{26}$ Alan Mason, "Bell and Fraser: A Partnership in Geology," Geological Society of New Zealand Historical Studies Group Newsletter 6 (1993): 26-31.

${ }^{27}$ Brian Marshall, "Mapping the Geology of Northland, New Zealand: N.Z. Geological Survey Bulletin No. 8 (Whangaroa Subdivision)," The Globe 82 (2017): 26-46.

${ }^{28}$ Peggy Burton, N.Z. Geological Survey 1865-1965, Information Series No. 52 (Wellington: Department of Scientific and Industrial Research, 1965), 49.

${ }^{29}$ Marshall, "Mapping the Geology of Northland," 26-46.

${ }^{30}$ Burton, N.Z. Geological Survey, 43.

${ }^{31}$ James Mackintosh Bell and Colin Fraser, The Geology of the Hokitika Sheet, North Westland Quadrangle, Bulletin No. 1 (Wellington: New Zealand Geological Survey Government Printer, 1906), 18.

${ }^{32}$ Patrick Marshall, The Geology of the Tuapeka District, Central Otago Division, Bulletin No. 19

(Wellington: New Zealand Geological Survey Government Printer, 1918).

${ }^{33}$ Appendices to the Journals of the House of Representatives, Annual Report of the New Zealand Geological Survey (Wellington: Government Printer, 1907), C9, p.5.

${ }^{34}$ James Mackintosh Bell, "A Physiographic Section through the Middle Island of New Zealand," Bulletin of the American Geographical Society 38 (1906): 273-81.

35 James Mackintosh Bell, “The Great Tarawera Volcanic Rift,” Geographical Journal 27, (1906): 36982.

${ }^{36}$ James Mackintosh Bell, "Some New Zealand Volcanoes," Geographical Journal 40 (1912): 8-23.

${ }^{37}$ Mason, "Bell and Fraser," 26-31.

${ }^{38}$ James Mackintosh Bell to Under-Secretary of Mines, 25 March 1907, "Bell Dr J. M. Director, Geological Survey,” ABLP W 47087214 GS 1907/14, Archives New Zealand, Wellington. Lectures were reported to include Boston, Harvard, Yale, and Princeton Universities. Pressure of time meant that scheduled lectures at Oxford and Cambridge did not take place ("Our London Letter," Nelson Evening Mail, 17 January 1908; “Dr. Bell's Return,” Grey River Argus, 7 January 1908).

${ }^{39}$ An example of the former is James Mackintosh Bell, "The Mineral Wealth of New Zealand," Proceedings of the Royal Colonial Institute 39 (1907-08): 37-55. "Scientific Notes and News," Science, 26, no. 666 (1907): 453-55.

${ }^{40}$ James Mackintosh Bell, "The Heart of the Southern Alps, New Zealand," Geographical Journal 30 (1907): 181.

${ }^{41}$ James Mackintosh Bell, “The Douglas Glacier and its Neighbourhood,” Geographical Journal 32 (1908): 121.

${ }^{42}$ Bell, "The Douglas Glacier," 128.

${ }^{43}$ Bell, "The Douglas Glacier," 121-34.

${ }^{44}$ Douglas Glacier, Evening Post 24 December 1907, 7; "Mineral Resources of New Zealand," Otago Witness, 8 January 1908, 88.

${ }^{45}$ James Mackintosh Bell, A Geographical Report on the Franz Josef Glacier with Topographical Maps and Data by Reginald Greville and Botanical Notes by Leonard Cockayne (Wellington: Government Printer, 1910), 10.

46 "The Great North Lecture by Dr Bell," Marlborough Express, 20 July 1906, 4; "Eighteen Months in the Canadian Far North," Evening Star, July 1906, 7; "In the Heart of the Southern Alps," Manawatu Times, 19 August 1909, 5; "New Zealand Volcanoes," New Zealand Herald, 6 August 1910, 4. The Lays

Journal of New Zealand Studies NS32 (2021), 108-122 https://doi.org/10.26686/jnzs.iNS32.6867 
Institute Library (and gymnasium) was founded in 1905 to further the education of boys. It functioned as a club and community centre for decades, before passing into the hands of the Auckland City Library.

The building was closed in 2019.

${ }^{47}$ Bell had written to RGS Secretary, Dr J. S. Keltie, offering his services to Scott's expedition, as well as writing directly to Scott himself. Having received a provisional yes from Scott, Bell than approached the New Zealand government. Bell seemed surprised that the official reply was that they could neither pay his salary nor spare him for the length of the expedition (1910-1913). He thought the New Zealand government would wish to have a representative on the trip which offered a "rare opportunity for scientific attainment" (Bell to Kinsey, 10 January 1910). Bell maintained a substantial correspondence, spread across 1910, with J. J. Kinsey, the expedition's official representative based in Christchurch, hoping that the government would change its mind. Kinsey could see this was not going to happen; Bell was less perceptive. This episode reveals another side of Bell, an impetuosity, and an inability to see why the government would not release him, and finally what his wife from 1909 may have thought about the plan. The letters form part of J. J. Kinsey's, "Correspondence re British Antarctica Expedition," MS Copy-Micro-0528-1 (Alexander Turnbull Library, Wellington).

${ }^{48}$ Bell, "The Douglas Glacier," 121-34.

${ }^{49}$ Aubury Strahan, "The Douglas Glacier and Its Neighbourhood: Discussion," Geographical Journal 32 (1908): 135.

${ }^{50}$ Douglas Freshfield, “The Douglas Glacier and Its Neighbourhood: Discussion," Geographical Journal 32 (1908): 137.

${ }^{51}$ Bell, The Wilds of Maoriland, 4.

52 Judith Binney, "Rua Kēnana Hepetipa," Dictionary of New Zealand Biography, Te Ara - the Encyclopedia of New Zealand, 1996, https://teara.govt.nz/en/biographies/3r32/rua-kenana-hepetipa.

${ }^{53}$ Bell, The Wilds of Maoriland, 113.

${ }^{54}$ Appendices to the Journals of the House of Representatives, Annual Report of the New Zealand Geological Survey (Wellington: Government Printer, 1908), C9 p. 10.

${ }^{55}$ Chapter 1 of The Wilds of Maoriland, "From Whangaroa to the North Cape," contains an account from the early years of Māori-Pākehā contact: the burning of the Boyd in 1809. The remains of the vessel lay in Whangaroa harbour. Bell wrote about Māori he encountered, but also, following his Great Bear Lake journey, displayed an ethnographic interest, recognising Cape Reinga as the place where the spirits of the dead wait before leaving for the ancestral homeland of Hawaiki, as well as actual early battle sites (where he referenced Percy Smith).

${ }^{56}$ Bell, The Wilds of Maoriland, 118.

${ }^{57}$ Bell, The Wilds of Maoriland, 115-16.

${ }^{58}$ Bell, The Wilds of Maoriland, 125.

${ }^{59}$ Bell, The Wilds of Maoriland, 126.

${ }^{60}$ Bell, The Wilds of Maoriland, 117.

${ }^{61}$ Bell, The Wilds of Maoriland, 128.

${ }^{62}$ Bell, The Wilds of Maoriland, 129.

${ }^{63}$ The wedding was described in some detail in the Evening Post, 23 September 1909, 8.

${ }^{64}$ Bell, The Wilds of Maoriland, 230.

${ }^{65}$ James Mackintosh Bell, "The Physical Features of New Zealand," Bulletin of the Geographical Society of Philadelphia 8 (1910): 1-16.

${ }^{66}$ Bell, Far Places, 122.

67 “Geologist's Death_Dr Mackintosh Bell," New Zealand Herald, 5 April 1934, 14.

${ }^{68}$ Bell, Side Lights. Bell in Far Places (108) says he was in Siberia the two years prior to the war; other sources suggest he returned to Canada in 1912. The discrepancy is not important for this present study. Bell's various narratives do not lack veracity, but on a number of small points he can be challenged. For example, his original appointment was not as Director of the NZGS, though he soon assumed the role;

Journal of New Zealand Studies NS32 (2021), 108-122 https://doi.org/10.26686/jnzs.iNS32.6867 
likewise, Marshall shows he spent less than two months and not four months at Whangaora, as claimed in The Wilds of Maoriland ("Mapping the Geology of Northland," 34).

69 "Scientific Lectures," Science 51, no. 1307 (1920): 60.

70 "Mining Investment," Evening Post, 10 March 1927; "Canada's High Destiny," Evening Star, 12

November 1926 [Father-in-law Harold Beauchamp's report on a seven-week trip to Canada, UK, and the continent].

71 “Obituary J. Mackintosh Bell," Evening Star, 2 April 1934, 9.

${ }^{72}$ James Mackintosh Bell, "Great Slave Lake," The Geographical Review 19 (1929): 556-80; "March Meeting 1932," Geographical Review 22 (1932): 481.

${ }^{73}$ Bell, Far Places.

${ }^{74}$ Bell, Far Places, xiii.

${ }^{75}$ Bell, Far Places, xiv.

${ }^{76}$ Bell, The Wilds of Maoriland, 4.

77 "Charles Camsell, Arctic Explorer, Son of the North," https://www.charlescamsell.com/.

${ }^{78}$ Gary Dunbar, "Harold Innis and Canadian Geography," The Canadian Geographer 29 (1985): 159-64.

${ }^{79}$ Bell, The Wilds of Maoriland, 244.

${ }^{80}$ Avrith-Wakeam, "George Dawson, Franz Boas," 202.

${ }^{81}$ Michael Roche, "George Jobberns and the Writing of New Zealand Geography: Textbooks from the 1920s to 1940s," New Zealand Geographer 67 (2011): 90-101. 